\title{
HUBUNGAN ANTARA KOMITMEN, KESELAMATAN KERJA DAN KINERJA KARYAWAN PT. BEHAESTEX BAGIAN PRODUKSI CABANG KEDIRI
}

\author{
Agus Dwi Prasetyo, Email: aidi_sqhappy@yahoo.co.id \\ Setyabudi Indaratono, Ph.D, Email setyabudi_indartono@uny.ac.id \\ Jurusan Manajemen, Fakultas Ekonomi, Universitas Negeri Yogyakarta
}

\begin{abstract}
Abstrak
Globalization changes every thing very quickly. Company's problem to improve performance indicated become more complex. Individual performances are needed to be payed in attention for management level to improve it. Commitmentandwork safety are indicated to affect employee's performance. This study aims to determine the effecton the safety and commitment on employee performance. PT. BEHAESTEX Kediri Branch Production Department was choosen tobe a sample for this study case. The results demonstrate that commitment and safety influence employee performancepositively.
\end{abstract}

Keyword: komitmen, keselamatan kerja, kinerja.

\section{Pendahuluan}

Pada era globalisasi ini segala sesuatunya mengalami perubahan yang begitu cepat, hal ini menuntut organisasi untuk lebih membuka diri terhadap beragam perubahan. Teknologiyang digunakan dalam produksi juga harus dapat menjadi modal utama untuk mengembangkan usaha dan memenangkan persaingan. Dengan begitu, perusahaan harus mampu mempertimbangkanlagi berbagai risiko yang akan di hadapi. Salah satunya adalah keselamatan kerja. Faktor ini bukan hanya sebagai pertimbangan risiko saja, tetapi juga merupakan salah satu penentu dari kinerja karyawan. Keselamatan kerja menjadi persoalan penting karenamerupakan salah satu cara untuk meningkatkan kinerja karyawan dalam mencapai sasaran perusahaan.

Permasalahan-permasalahan yang dihadapi perusahaan sangatlah kompleks. Semakin ketatnya persaingan, membuat perusahaan harus lebih pandai dalam menyusun strategi, baik dalam keuangan, pemasaran, operasional dan sumber daya manusia. Perusahaan harus mampu meningkatkan kinerja karyawannya untuk bisa 
memberikan terobosan-terobosan baru agar memenangkan persaingan. Salah satu faktor yang dapat mempengaruhi kinerja adalah adanya keselamatan kerja yang nantinya memberikan rasa nyaman kepada karyawan. Penelitian sebelumnya menunjukkan bahwa keselamatan kerja berpengaruh pada kinerja. Penitian ini diantaranya dilakukan oleh (Barlin, Kelloway, dan Iverson, 1997) yang menyatakan bahwa kualitas kinerja yang tinggi akan mempengaruhi keselamatan kerja. Penelitian lain (yang dilakukan oleh Iverson, Zacharatos and Barling, 2005) menunjukkan bahwa sistem kinerja yang tinggi berpengaruh terhadap tingkat keselamatan kerja.

Kinerja seorang karyawan merupakan hal yang bersifat individual, karena setiap karyawan mempunyai tingkat kemampuan yang berbeda - beda dalam mengerjakan tugasnya. Kondisi psikologis karyawan terhadap perusahaan juga mempengaruhi kinerja. Salah satu sikap karyawan yang mempengaruhi kinerja adalah komitmen. Komitmen lebih dari sekedar keanggotaan formal, karena meliputi sikap menyukai organisasi dan kesediaan untuk mengusahakan tingkat upaya yang tinggi bagi kepentingan organisasi demi pencapaian tujuan (Robbins SP dan Judge, 2007).Banyak penelitian telah mengkaji hubungan antara komitmen dan kinerja karyawan. Salah satunya menyatakan bahwa pengaruh komitmen terhadap kinerja karyawan, dikatakan bahwa komitmen organisasi dan kinerja kerja itu secara positif berhubungan satu sama lain (Sundar, Murugarathinam, Kumar, 2011) dan dalam penelitian lain (Brett, Crondan Solwm, 1995) yang mengeksplorasi hubungan antarakomitmen dan prestasi kerjamenggunakan ketergantungan ekonomipada pekerjaan sebagai moderator, melaporkan bahwa hubungan antara komitmen dan kinerja berpengaruh kuat untuk persyaratan pada organisasi yang keuangan rendah dibandingkan mereka dengan kebutuhan keuangan tinggi. Oleh karena itu sangat penting untuk melanjutkan penelitian terkait dengan hal-hal yang mempengaruhi kinerja dalam sebuah perusahaan. Sehingga 
penilitan ini yang mengkaji pengaruh komitmen dan keselamatan kerja dengan kinerja karwayan akan memberikan banyak kontribusi baik terhadap penerapan manajemen SDM maupun pengembangan teori MSDM. Kontribusi tersebut diantaranya adalah perbaikan kinerja, perencanaan dan pengembangan karir, menjamin kesempatan kerja yang setara, mendeteksi faktor eksternal yang mempengaruhi kinerja, memberikan umpan balik bagi departemen SDM (Werther \& Davis 1996).

\section{Studi Literatur}

\section{Kinerja Karwayan}

Kinerja merupakan salah satu faktor yang dapat meningkatkan efektifitas dalam suatu perusahaan. Sistem kinerja yang tinggi dapat menciptakan lingkungan kerjayang lebih baik bagi karyawan, sehingga menyebabkan peningkatankualitas kehidupan kerja.

Kinerja (prestasi kerja) karyawan adalah prestasi aktual karyawan dibandingkan dengan prestasi yang diharapkan dari karyawan. Prestasi kerja yang diharapkan adalah prestasi standar yang disusun sebagai acuan sehingga dapat melihat kinerja karyawan sesuai dengan posisinya dibandingkan dengan standar yang dibuat. Kinerja adalah keluaran yang dihasilkan oleh fungsi-fungsi atau indikatorindikator suatu pekerjaan atau suatu profesi dalam waktu tertentu (Wirawan. 2009).

Banyak faktor-faktor yang dapat memengaruhi kinerja individu tenaga kerja, yaitu kemampuan mereka, motivasi, dukungan yang diterima, keberadaan pekerjaan yang mereka lakukan, dan hubungan mereka dengan organisasi/lingkungan organisasi (Robert L. Mathis dan John H. Jackson. 2001). Sehingga kinerja merupakan kualitas dan kuantitas dari suatu hasil kerja (output) individu maupun kelompok dalam suatu aktivitas tertentu yang diakibatkan oleh kemampuan alami atau kemampuan yang diperoleh dari proses belajar serta keinginan untuk berprestasi. Menurut para ahli (Mangkunegara. 2000) menyatakan bahwa faktor yang memengaruhi kinerja antara lain faktor kemampuan dan faktor motivasi. 
Kinerja juga sering kali identik dengan kemampuan seorang auditor bahkan berhubungan dengan komitmen terhadap suatu profesi (Larkin dan Seweikart, 1992).

Karakteristik pekerjaan yang berhubungan dengansistem kinerja kerja memungkinkan karyawan untuk mengalamikebermaknaan dalam pekerjaan mereka, tanggung jawab lebih besar dalam pekerjaan mereka,dan lebih baik menggunakanpengetahuan dan keterampilan, yang menyebabkan peningkatankepuasan dan keselamatan dalampekerjaan mereka (misalnya, Berg, 1999; Godard,2001a; Havlovic, 1991 dalam Barlin, Kelloway, dan Iverson, 1997).

\section{Komitmen Karwayan}

Komitmen organisasi merupakan suatu hal yang penting dalam penelitian perilaku organisasi. Bagian ini mengarah pada luasnya hubungan antara komitmen organisasi dengan berbagai macam perilaku di tempat kerja (Porter, 1974; Koch and Steers, 1978; Angel and Perry, 1981 dalam Angle and Perry, 1981). Komitmen merupakan suatu keadaan dimana seorang individu memihak organisasi serta tujuan-tujuan dan keinginannya untuk mempertahankan keangotaannya dalam organisasi (Robbins dan Judge. 2007)

Komitmen pegawai pada organisasi tidak terjadi begitu saja, tetapi melalui proses yang cukup panjang dan bertahap. Menurut Steers (dalam Sopiah, 2008) menyatakan bahwa ciri pribadi pekerja, ciri pekerjaan, dan pengalaman kerja dapat mempengaruhi tingkat komitmen karyawan.

Individu yang memiliki komitmen organisasi yang tinggi memiliki kondisi : (a) individuindividu tersebut lebih mampu menyesuaikan diri; (b) jumlah karyawan yang keluar-masuk (turnover) lebih sedikit; (c) kelambatan dalam bekerja lebih sedikit dijumpai; (d) kepuasan kerja lebih tinggi (Bateman dan Strasser, 1984). Mathieu dan Zajack (dalam Muchinsky, 1993: 288-289) menyatakan bahwa seseorang yang terlalu berkomitmen pada organisasi akan cenderung mengalami stagnasi dalam kariernya serta cenderung 
berkurang pengembangan dirinya (self development); dan bila komitmen mencerminkan identifikasi dan keterlibatan dalam organisasi, maka organisasi akan mendapat keuntungan dengan berkurangnya turnover, adanya prestasi yang lebih baik.

Sundar, Murugarathinam, Kumar (2011) melaporkan bahwa jika seorang karyawan memiliki komitmen maka kinerjanya akan baik. dalam penelitian lain (Brett, Crondan Solwm, 1995)yangmengeksplorasihubungan antarakomitmen danprestasi kerjamenggunakanketergantungane konomipada pekerjaansebagai moderator, melaporkanbahwa hubungan antarakomitmen dankinerjaberpengaruh kuatuntukpersyaratanpada organisasi yang keuangan rendahdibandingkan merekadengan kebutuhankeuangantinggi.

Dari beberapa pengertian di atas jelas bahwa komitmen merupakan bagian yang terkait dengan kinerja karyawan dalam hubungannya dengan pekerjaannya. Dalam sebuah komitmen juga memiliki unsur atau komponen yang saling berhubungan. Ketika semua komponen terpenuhi maka semakin besar komitmen karyawan dalam pekerjaannya. Menurut Meyer, Allen \& Smith (1993) komitmen organisasi terdiri dari 3 komponen yaitu:

1. Komitmen kerja afektif (affective occupational commitment). Komitmen sebagai ketertarikan afektif/psikologis karyawan terhadap pekerjaannya. Komitmen ini menyebabkan karyawan bertahan pada suatu pekerjaan karena mereka menginginkannya.

2. Komitmen kerja kontinuans (continuance occupational commitment)Mengarah pada perhitungan untung-rugi dalam diri karyawan sehubungan dengan keinginannya untuk tetap mempertahankan atau meninggalkan pekerjaannya. Artinya, komitmen kerja disini dianggap sebagai persepsi harga yang harus dibayar jika karyawan meninggalkan pekerjaannya. Komitmen ini menyebabkan karyawan bertahan pada suatu pekerjaan 
karena mereka Keselamatan kerja

membutuhkannya.

3. Komitmen kerja normatif (normative occupational commitment). Komitmen sebagai kewajiban untuk bertahan dalam pekerjaannya. Komitmen ini menyebabkan karyawan bertahan pada suatu pekerjaan karena mereka merasa wajib untuk melakukannya serta didasari pada adanya keyakinan tentang apa yang benar dan berkaitan dengan moral.

Tidak semua komponen di atas dimiliki oleh karyawan, tetapi lebih baik lagi jika ketiga komponen tersebut dimiliki oleh karyawan. Sebagai contoh, ketika komponen affective occupational commitment lebih dominan maka karyawan tersebut merasa lebih cocok dengan bidang pekerjaannya, baik itu secara emosional maupun kesesuaian antara karakteristik pekerjaan dengan dirinya.Sehingga dapat diajukan hipotesis:

Hipotesis 1: komitmen memiliki pegaruh positif terhadap kinerja karyawan secara signifikan
Keselamatanmerupakan

masalah besarbagi organisasi,sebagai sumberbiaya langsungdan tidak langsungyang cukup besar (Neal \& Griffin, 2002).Menurut Suma'ur (1986:1) keselamatan kerja merupakan keselamatan yang bertalian dengan mesin, pesawat, alat kerja, bahan dan proses pengolahan, landasan tempat kerja dan lingkungannya serta cara - cara melakukan pekerjaan.

Tindakan manajemen secara langsung mempengaruhi persepsi keselamatan iklim (Zacharatos, Barling, And Iverson, 2005).Misalnya, ketika manajer memanggil perhatian pada pentingnya keselamatan, pengaruh ideal dengan demikian menampilkan, karyawan persepsi iklim keamanan yang ditingkatkan. Keamanan pekerjaan mendorong perspektif jangka panjang dan merupakan investasi waktu dan sumber daya karyawan, yang akan menjadi membalas dalam hal kesetiaan kepada organisasi (Tsui, Pearce,Porter,\&Tripoli, 1997). Trust dimanajemen juga akan ditimbulkan 
dari kerja keamanan, yang diinginkan sejauh kepercayaan manajemen terkait dengan kinerja organisasi(McAllister, 1995).

Pada tingkat karyawan, ada juga bukti yang menunjukkan bahwa kinerja tinggi sistem kerja meningkatkan kepuasan kerja(Berg, 1999) dan mengurangi kelelahan karyawan (Godard, 2001a).Yang penting adalah bahwa sekarang ada indikasi bahwa globalkinerja tinggi sistem kerja mempengaruhi keselamatan langsung di perusahaan tingkat dan tidak langsung di tingkat karyawan (Zacharatos \&Barling, 2001).

$$
\text { Penelitian sebelumnya }
$$
menunjukkan bahwa keselamatan kerja berpengaruh pada kinerja. Penitian ini diantaranya dilakukan oleh (Barlin, Kelloway, dan Iverson, 1997) yang menyatakan bahwa kualitas kinerja yang tinggi akan mempengaruhi keselamatan kerja. Penelitian lain (yang dilakukan oleh Iverson, Zacharatos and Barling, 2005) menunjukkan bahwa sistem kinerja yang tinggi berpengaruh terhadap tingkat keselamatan kerja.

$$
\text { Ada beberapa faktor }
$$

yangmendukung hubungan

antarakerja berkualitas tinggidan keselamatan kerja. Pertama, otonomi merupakan aspek penting tinggi kualitas kerja. Tapi untuk otonomi yang akan digunakan dengan sukses, karyawan harus memiliki keterampilan yang dibutuhkan, menunjuk pentingnya pelatihan sebelumnya(Goodman \& Garber, 1988; Parker \& Wall,1998). Anteseden kinerja merupakan faktor yang mempengaruhi perilaku melalui pengaruhnya terhadap pengetahuan, keterampilandan motivasi. Ada berbagai faktor individu dan lingkungan yang diketahui mempengaruhi perilaku kerja, termasuk kemampuan, kepribadian, dan iklim organisasi (Neal \&Griffin1999). Model inimenunjukkan bahwa iklim keselamatan adalah salah satu anteseden banyak potensi perilaku keselamatan. Sehingga dapat diajukan hipotesis:

Hipotesis 2: keselamatan kerja memiliki pegaruh positif terhadap kinerja karyawan. 


\section{Metodologi}

Riset ini melibatkan karyawan PT. BEHAESTEX Bagian Produksi Cabang Kediri sebagai responden. Sebanyak 150 angket valid didapatkan dari penyebaran sejumlah 160 angket ke seluruh karyawan PT. BEHAESTEX Bagian Produksi. Partisipan dari riset ini terdiri dari karyawan dengan ratarata usia 28 tahun, laki-laki sejumlah 90 orang, perempuan sejumlah 60, rata-rata latar belakang pendidikan sekolah menengah pertama (SMP), rata-rata pengalaman atau lama kerja 7 tahun.

Alat ukur

Alat ukur yang digunakan untuk mengetahui komitmen diambil dari (Aaron Cohen 1993; Sowmya and Panchanatham 2011; Neeru Malhotra and Avinandan Mukherjee, 2004.), yang diantaranya menyatakan akan sangat berat bagi saya untuk meninggalkan perusahaan ini sekarang, sekalipun saya menginginkannya. Alat ukur keselamatan kerja diambil dari
(Julian Barling, E. Kevin Kelloway, Catherine Loughlin: 2002), yang diantaranya menyatakan Saya selalu memakai alat pelindung atau pakaian yang dibutuhkan oleh pekerjaan saya. Dan alat ukur kinerja di gunakan dari hasil riset (Fien Vanommeslaeghe, Nele Verniers 2010; Bradley E. Wright 2004), yang diantaranya menyatakan Saya mampu menyelesaikan tugas tepat waktu. Skala likert 1 hingga 5 digunakan untuk scoring pengukuran.

\section{Hasil Penelitian}

Nilai model fit menghasilkan Degrees of Freedom $=186$, ChiSquare $=216.22$, Root Mean Square Error of Approximation (RMSEA) = 0.033, Normed Fit Index (NFI) = 0.24 , Non-Normed Fit Index (NNFI) $=0.45$, Comparative Fit Index (CFI) $=0.51$, Root Mean Square Residual $($ RMR $)=0.023$, Goodness of Fit Index $(\mathrm{GFI})=0.88$, dan Adjusted Goodness of Fit Index (AGFI) $=0.85$. Hal ini menunjukan bahwa model yang diajukan cukup baik. 


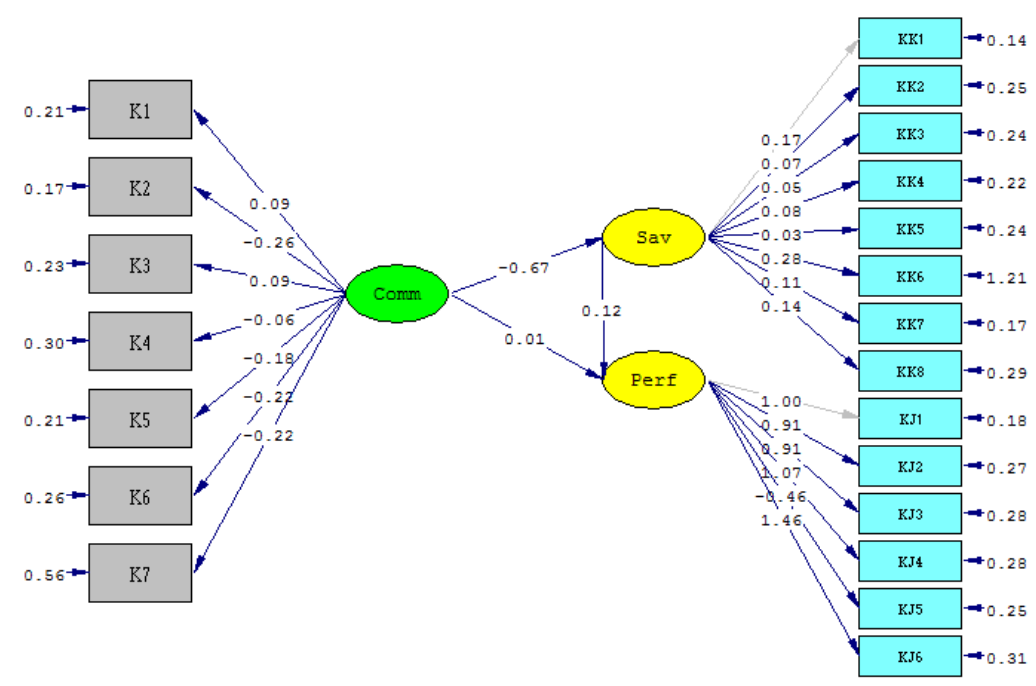

Gambar 1. Hasil Analisi Model Penelitian

Dari perhitungan spss didapatkan dalam hubungan jenis kelamin dengan pendidikan $=-0,030$ $<0,05$, dengan status $=-0,144<0,05$, dengan komitmen $=-0,031<0,05$, dengan keselamatan kerja $=0,054$ $<0,05$, dengan kinerja $=0,025<0,05$. Sehingga tidak berkorelasi secara signifikan. Pendidikan dengan Status $=0,057>0,05$, dengan Komitmen $=0,006>0,05$, dengan keselamatn kerja $=0,087<0,05$, dengan kinerja $=-0,161^{*}<0,05$, sehingga hubungan pendidikan dengan status, komitmen dan keselamatan tidak berkorelasi secara signifikan, sedangkan dengan kinerja terlihat ada korelasi cukuo signifikan. Status dengan komitmen
$=0,143>0,05$, dengan keselamatan kerja $=-0,034<0,05$, dengan kinerja $=0,202^{* *}>0,05$, sehingga hubungan Status dengan komitmen dan keselanatan kerja tidak berkorelasi secara signifikan, sedangkan dengan kinerja berkorelasi secara signifikan. Komitmen dengan keselamatan kerja $=0,171^{* *}>0,05$, dengan kinerja $=0,364^{* *}>0,05$, sehingga hubungan komitmen dengan keselamatan kerja dan kinerja berkorelasi secara signifikan. Keselamatan kerja dengan kinerja $=0,241^{* *}>0,05$ sehingga hubungan keselamatan kerja dengan kinerja berkorelasi secara signifikan. Dengan demikian dapat dikatakan bahwa komitmen dan keselamatan kerja berpengaruh 
terhadap kinerja, sehingga hipotesis

1 dan hipotesis 2 diterima.

Table 1.Nilai rerata, Standar deviasi, korelasi, cronbach alfa

\begin{tabular}{lrrrrrrrr}
\hline & Rerata & \multicolumn{1}{l}{ SD } & 1 & \multicolumn{1}{c}{ S } & 3 & 4 & 5 & 6 \\
\hline 1. Jenis Kelamin & 1.42 & .495 & & & & & & \\
2. Pendidikan & 2.03 & .750 & -.030 & & & & & \\
3. Status & 1.39 & .542 & -.144 & .057 & & & & \\
4. Komitmen & 4.2505 & .217 & -.031 & .006 & .143 & $\mathbf{0 . 0 7}$ & & \\
5. Keselamatan kerja & 4.0408 & .239 & -.054 & .087 & -.034 & $.171^{*}$ & $\mathbf{0 . 2 4}$ & \\
6. Kinerja & 4.3067 & .189 & .025 & $-.161^{*}$ & $.202^{*}$ & $.364^{* *}$ & $.241^{* *}$ & $\mathbf{0 . 1 9}$ \\
\hline
\end{tabular}

\section{Kesimpulan}

Kerangka teoritis keselamatan kerja (Barlin, Kelloway, dan Iverson, 1997). Hasil penelitian memperkuat penelitian sebelumnya (Iverson, Zacharatos and Barling, 2005) bahwa keselamatan kerja berpengaruh terhadap kinerja. Demikian juga dengan komitmen (Sundar, Murugarathinam, Kumar, 2011) bahwa dengan adanya komitmen akan meningkatkan kinerja karyawan. Sehingga dapat disimpulkan bahwa komitmen dan keselamatan kerja berhubungan dengan kinerja karyawan. Temuan ini signifikansi konseptual, metodologis, dan praktis.

Temuan dari penelitian ini masih memiliki beberapa keterbatasan. Oleh karena itu perlu adanya penelitian lebih lanjut untuk memperbaiki, memperkuat, dan bahkan menemukan temuan baru.

Penelitian dilakukan hanya dengan menganalisa pengaruh dari keselamatan kerja dan komitmen terhadap kinerja. Agar dapat kesimpulan yang lebih luas maka sebaiknya dilakukan penelitian lagi tentang pengaruh motivasi, gaya kepemimpinan, serta lingkungan organisasi sehingga akan meningkatkan pemahaman kita tentang bagaimana meningkatkan suatu kinerja karyawan.

Daftar Pustaka
Aaron Cohen (1993), Work
Commitment In Relation To
Withdrawal Intentions And
Union Effectiveness. Journal
Of Business Research, Vol. 26,
Pp. 75-90
Anne S. Tsui, Jone L. Pearce, Angela
M, Tripoli (1997). Alternative
Approaches To The Employee-
Organization Relationship:
Does Investment In Employees
Pay Off?. Academy Of


Management Journal, Vol. 40, No. 5, 1089-1121.

Bateman, T Dan S. Strasser (1984). A Longitudinal Analysis Of Antecedents Of The Antecedent Of Organizational Commitment. Academy Of Management Journal 27: 95112.

Berg, P (1999). The Effects Of High Performance Work Practices On Job Satisfaction In The United States Steel Industry. Relations Industrielles/Industrial Relations, 54, 111-134.

Bradley E. Wright, University Of North Carolina At Charlotte (2004), The Role Of Work Context In Work Motivation: A Public Sector Application Of Goal And Social Cognitive Theories, Journal Of Public Administration Research And Theory, Vol. 14, No. 1, Pp. 5978.

Daniel J. Mcallister (1997). The Second Face Of Trust: Reflections On The Dark Side Of Interpersonal Trust In Organizations. Research On Negotiation In Organizations, Volume 6, Pages 87-111.

Fien Vanommeslaeghe, Nele Verniers, University Of Ghent (2010), The Impact Of Enhancing Autonomous Motivation On Financial Performance, Master's Dissertation Presented To Obtain The Degree Of Master In Business Economics.

Godard, J (2001a). High Performance And The Transformation Of Work? The Implications Of Alternative Work Practices For The Experience And Outcomes
Of Work. Industrial And Labor Relations Review, 54, 776-805. Goodman, P. S., \& Garber, S (1988). Absence And Accidents In A Dangerous Environment. Journal Of Applied Psychology, 73, 81-86.

Harold L. Angle; James L. Perry (1981). An Empirical Assessment Of Organizational Commitment And OrganizationalEffectiveness. Administrative Science Quarterly, Vol. 26, No. 1, Pp. 114.

Julian Barlin, E. Kevin Kelloway, And Roderick D. Iverson (1997), High-Quality Work, Job Satisfaction And Occupational Injuries, Department Of Workplace Relations And Small Business, No. 16,466

Julian Barling, E. Kevin Kelloway, Catherine Loughlin (2002), Development And Test Of A Model Linking Safety-Specific Transformational Leadership And Occupational Safety, Journal Of Applied Psychology, Vol. 87, No. 3, Pp. 488-496

K.R.Sowmya1, N. Panchanatham2, 1Department Of Management Studies, St. Peter's College OfEngineering \& Technology, Avadi, Chennai, Tamil Nadu, India, 2Department Of Business Administration, Annamalai University, Chidambaram, Tamil Nadu, India: 201. Factors Influencing Organizational Commitment Of Banking Sector Employees. Journal Of Economics And Behavioral Studies Vol. 2, No. 1, Pp. 19-25

K. Sundar, A. Murugarathinam, Ashole Kumar (2011), Job 
Performance

And

Organisational Commitment A

Research Study, The

International Journal's, Vol. 01,

No. 01

Mangkunegara, Prabu, Anwar (2004). Manajemen Sumber Daya Manusia Perusahaan. PT Rineka Cipta, Jakarta.

Meyer, J. P. Allen, N. J. Smith, C. A (1993). "Commitment To Organizations And Occupations: Extension And Test Of A Three-Component Conceptualization". Journal Of Applied Psychology, 78, 4, 538552.

Muchinsky, P (1993). Psychology Applied To Work: An Introduction To Industrial/Organizational Psychology. L.A: Brooks/Cole

Neal, A. \& Griffin, M. A (2002). Safety Climate And Safety Behavior. Australian Journal Of Management, 27(Special Issue).

Neeru Malhotra And AvinanDan Mukherjee (2004). The Relative Influence Of Organisational Commitment And Job Satisfaction On Service Quality Of Customer Employees In Banking Call Centres. The Journal Of Services Marketing; 18, 2/3; Proquest Research LibraryPg. 162.

Robbins SP, Dan Judge (2007). Perilaku Organisasi, Jakarta : Salemba EmpatBrett, J., Cron, W., \& Slocum, J (1995). Economic Dependency On Work: A Moderator Of The
RelationshipBetween Organizational Commitment And Performance. Acaderny Of Management Journal, 38, 261-71.

Robert L. Mathis \& John H. Jackson (2001). Manajemen Sumber Daya Manusia. Jakarta : Salemba Empat.

Roderick D. Iverson, Anthea Zacharatos And Julian Barling (2005), High-Performance Work Systems And Occupational Safety, Journal Of Applied Psychology, Vol. 90, No. 1, 77-93

Sopiah (2008). Perilaku Organisasi, Yogyakarta : Andi

Suma'mur (1986). Keselamatan Kerja Dan Pencegahan Kecelakaan. Penerbit Gunung Agung, Jakarta.

Werther, W.B. \& Davis, K (1996).Human Resources And Personnel Management, $5^{\text {th }}$ Ed., Boston: Mcgraw-Hill

Wirawan (2009). Evaluasi Kinerja Sumber Daya Manusia. Jakarta : Salemba Empat 